\title{
ON STRUCTURAL ASPECTS OF TEXTURE CHANGES DURING ROLLING OF Zr-2.5\%Nb ALLOY
}

\author{
Victor Grytsyna ${ }^{1}$, (D)Dmitry Malykhin ${ }^{1 *}$, (D)Tetiana Yurkova ${ }^{1}$, Costiantyn Kovtun $^{3}$, \\ Tetiana Chernyayeva $^{1}$, (Dennadiy Kovtun ${ }^{1,2}$, Iryna Tantsura ${ }^{1}$, Victor Voyevodin ${ }^{1}$ \\ ${ }^{1}$ NSC "Kharkiv Institute of Physics \& Technology" NASU, Kharkiv, 61108, st. Akademicheskaya 1, Ukraine \\ ${ }^{2}$ V.N. Karazin Kharkiv National University, Kharkiv, 61022, Svobody Sq. 4, Ukraine. \\ ${ }^{3}$ Public Enterprise «NTC «Beryllium», NASU, Kharkiv, 61108, st. Akademicheskaya 1, Ukraine \\ *E-mail:dmitr.malykhin@gmail.com \\ Received July 15, 2019; revised August 7, 2019; accepted August 27, 2019
}

Using X-ray structural analysis, features of changes in characteristics of crystallographic texture during cold working of $\mathrm{Zr}-2.5 \% \mathrm{Nb}$ alloy plates by longitudinal and cross rolling has been investigated. To make original plates, longitudinal fragments and rings of $\varnothing 15.0 \times 1.5 \mathrm{~mm}^{2}$ tube annealed at $580{ }^{\circ} \mathrm{C}$ were used. The plates were rolled at room temperature to the degrees in the range from 6 to $56 \%$ with $5 \ldots 7 \%$ per pass and the rate of $5 \ldots 10 \mathrm{~s}^{-1}$. Using the method of inverse pole figures with measuring by the Bragg-Brentano optical scheme, densities of reflections along normal to plane of the plates (pole densities) was determined. Based on this, distributions of orientations of $c$-axes of hep lattice of the material have been analyzed. Local features of the distributions, which were attributed to signs of twinning effects in texture changes in the alloy, are revealed. At subsequent analysis, an effect of strain nonuniformity associated with prehistory of the plates was taken into account. It is established that the second stage of (moderate) changes in Kearns textural coefficient of the plates with the deformation degrees differs from the initial stage of accelerated changes by activation of compression twins. By the method of tilt scanning (of rocking curves) around the Bragg-Brentano position at registration of (0004) reflection intensities, changes in orientation distributions of $c$-axes in longitudinal and cross section of the plates for both parties were investigated. It is noted that the main textural changes in process of deformation of the plates occur in the crosssectional plane of the original tube and are most expressed on the cross-rolling plates. The doublet in the distributions of $c$-axes, characteristic for rolling texture of hep metals of titanium subgroup, was noted just at the second stage of the texture changes in the material. Its directionality is mainly associated with the plane of cross-section of the original tube. A connection is revealed between features of the pole density distributions and expression degree of the textural doublet on the rocking curves. According to the results obtained and analysis of other publications, twinning nature of the textural doublet was confirmed and a schematic sequence of its formation was proposed with participation of compression twins of $\{11 \overline{2} 2\}\langle\overline{1} \overline{1} 23\rangle$ system and tensile twins of $\{10 \overline{1} 2\}\langle\overline{1} 011\rangle$ and $\{11 \overline{2} 1\}\langle\overline{1} \overline{1} 26\rangle$ systems.

KEYWORDS: zirconium alloys, rolling, XRD, texture, twinning.

This work is a continuation of studies of regularities and mechanisms of texture changes during plastic deformation of the $\mathrm{Zr}-2.5 \% \mathrm{Nb}$ alloy widely used in nuclear industry [1]. Texture of products with hep lattice of material, in particular, of zirconium alloys, is a factor of anisotropy of the materials and many of its properties. They are mechanical, electrical and thermal characteristics, etc. Effect of radiation growth of tubes made of zirconium alloys in the reactor core is closely related to crystallographic texture.

A special feature of the work is a study of material with a lowered initial texture and, herewith, the use the method of inverse pole figures (IPFs) with sample scanning by the usual diffractometric scheme. From the textural method of direct pole figures, widely used recently, this method differs by its significant simplicity. In addition, this method has advantages in accuracy of determining of certain texture parameters of the materials directly related to the listed characteristics of products. All this as a whole gives the possibility to study quantitative regularities of changes in texture characteristics depending on physical and technological factors.

The main such parameter, which was proposed for studies of samples of zirconium alloys, is Kearns textural coefficient [2]. This is a characteristic expressing degree of directionality of $c$-axes of crystalline hep cell of grains in polycrystalline material along a given geometric direction in a product:

$$
f_{k}=\left\langle\cos ^{2} \alpha_{k i}\right\rangle
$$

where $\alpha_{k i}$ are the angles between a given direction $(k)$ and orientations $(i)$ of $c$-axes.

Most of the listed product characteristics, dependent on crystallographic anisotropy of zirconium alloys, are associated with the $f$ coefficient linear dependence. In particular, the textural coefficient of radiation growth of zirconium elements of reactor core and fuel assembly components is unambiguously connected with it: $G=1-3 f[3]$.

In the previous work [4], studies were carried out on regularities of changes in the textural coefficient depending on degrees of deformation by longitudinal and cross rolling of plates made from fragments of a tube of this alloy. Existence of two stages was revealed: the initial stage of an increased rate of growth of the coefficient and the subsequent moderate stage. By analyzing dynamic of $c$-axes distributions with deformation degrees of the alloy, the leading role of twinning in the changes on the initial stage of deformation was established. 
The purpose of this work is to continue the studies of role of structural mechanisms in regularities of changes in crystallographic texture of this alloy at longitudinal and cross rolling. This is envisaged by implementation additional studies with detailed analysis of texture of samples made and investigated at the previous stage of work. In this regard, we use additional techniques and approaches to X-ray analysis of texture.

\section{EXPERIMENTAL}

On material [4]. For making samples of $\mathrm{Zr}-2.5 \% \mathrm{Nb}$ alloy, the original material was a tube $\varnothing 15.0 \times 1,5 \mathrm{~mm}^{2}$ of RBMK reactor fuel assemblies with final annealing at $580{ }^{\circ} \mathrm{C}$ for $3 \mathrm{~h}$.

Samples in the form of plates were made of longitudinal fragments and rings of the tube, $40 \times 20 \mathrm{~mm}^{2}$ and $20 \times 10 \mathrm{~mm}^{2}$ of size, respectively. The plates were annealed at $580{ }^{\circ} \mathrm{C}$ for $24 \mathrm{~h}$ in $1.5 \cdot 10^{-3} \mathrm{~Pa}$ vacuum, and then etched up to $65 \mu \mathrm{m}$.

The plates were rolled at room temperature from 6 to $55 \%$ on the whole with a step of $5 . .7 \%$ per pass and a speed of $5 \ldots 10 \mathrm{~s}^{-1}$ without intermediate annealing. According to the nature of texture of the original tube [4], the rolling was considered as an analogue of longitudinal (for plates of longitudinal fragments) and cross rolling (for plates of rings).

Methods. The IPF method with the principle of calculating the textural coefficient is described in [4].

At this stage, as one of the research approach, we analyzed the distribution of orientation of $c$-axes along the normal to surface of the samples - density of $c$-axes distribution by the angle of their deviation from the normal direction (ND), regardless of other coordinate angles. As an analogue of such a distribution, the pole density values $\left(P_{(h k l)}\right)$ were used. In this case, only pyramidal planes of the first kind - $(h 0 \bar{h} l)$ - were taken into account. Such a group represents the densest sequence of $P_{(h k i l)}$ values, where the result of the changes may be most noticeable.

As a second additional method of analysis, the technique of tilt scanning of plates (rocking curve measurements) was used. This is aimed at analyzing $c$-axes distribution within the planes of orthogonal plate section. The distributions of (0004) X-ray intensities were analyzed when the shooting direction deviated from the normal to the plate plane (ND) towards the rolling direction (RD) and towards the transverse direction (TD) associated with the rolling geometry.

To eliminate the effects associated with misalignment of the optimal X-ray optic scheme, a wide receiving slit of the counter was used, and the intensity measured was averaged over two opposite tilts.

\section{RESULTS END DISCUSSION \\ Graphical regularities}

Fig. 1,2 show the pole density distribution $\left(P_{(h k l)}\right.$; $c$-axes distributions) for $(h 0 \bar{h} l)$ reflections in the ND direction of plates, including (0002) and (1010) reflections. Distributions are presented in $\cos ^{2} \alpha$ coordinates for the initial and deformed state of samples after longitudinal (Fig. 1) and cross rolling (Fig. 2). The graphs, presented in commonlogarithmic scale, are located with deformation degrees above each other through the single-unit interval of the ordinate grid.
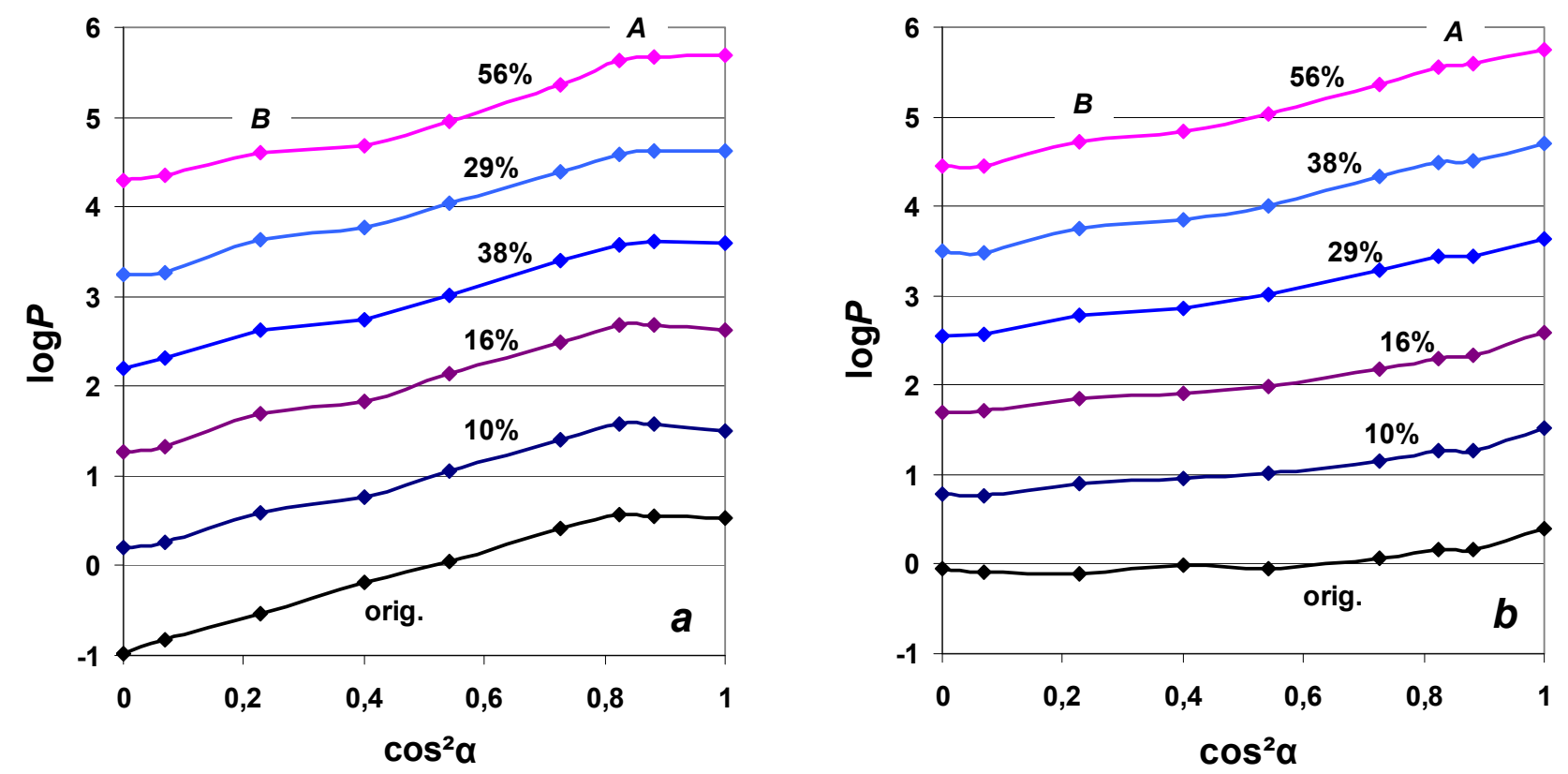

Fig. 1. $C$-axes distributions at $(h 0 \bar{h} l)$-reflecting positions of grains in ND direction of longitudinally-rolled $\mathrm{Zr}-2.5 \% \mathrm{Nb}$ plates on texture measurements on the inside (a) and outside (b) of original tube. 

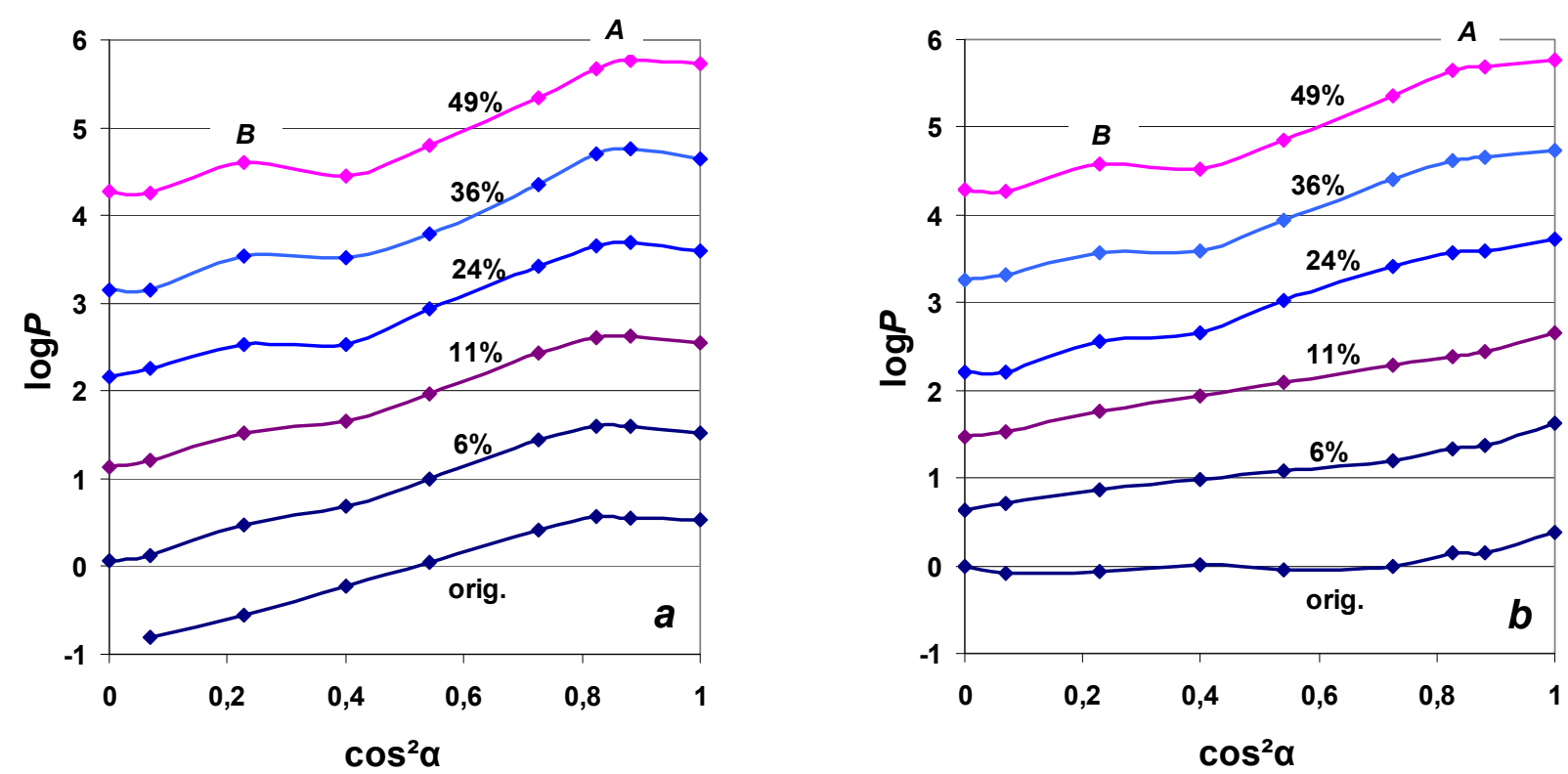

Fig. 2. $C$-axes distributions at $(h 0 \bar{h} l)$-reflecting positions of grains in ND direction of cross-rolled $\mathrm{Zr}-2.5 \% \mathrm{Nb}$ plates in presentation of texture data measured on the inside (a) and outside (b) of original tube.

The most characteristic regularities should be noted on the data obtained from the surface of the plates on the inside of the original tube (Fig. 1a, 2a). The main course of the graphs in logarithmic representation of data is linear and uniform for all states and for each of two batches. This corresponds to the second stage of the change of the textural coefficient $(f)$ with the plate deformation - to the stage of moderate changes [4]. These data are represented by graphs with light circles in Fig. 3a,b. They indicate that for the texture of the inner surface areas of the tube, its blanks, it is sufficient to reach the second stage by straightening the blanks, which for these areas is similar to rolling by $10 \%$ regardless of the subsequent preliminary annealing the samples in the $\alpha$-phase.
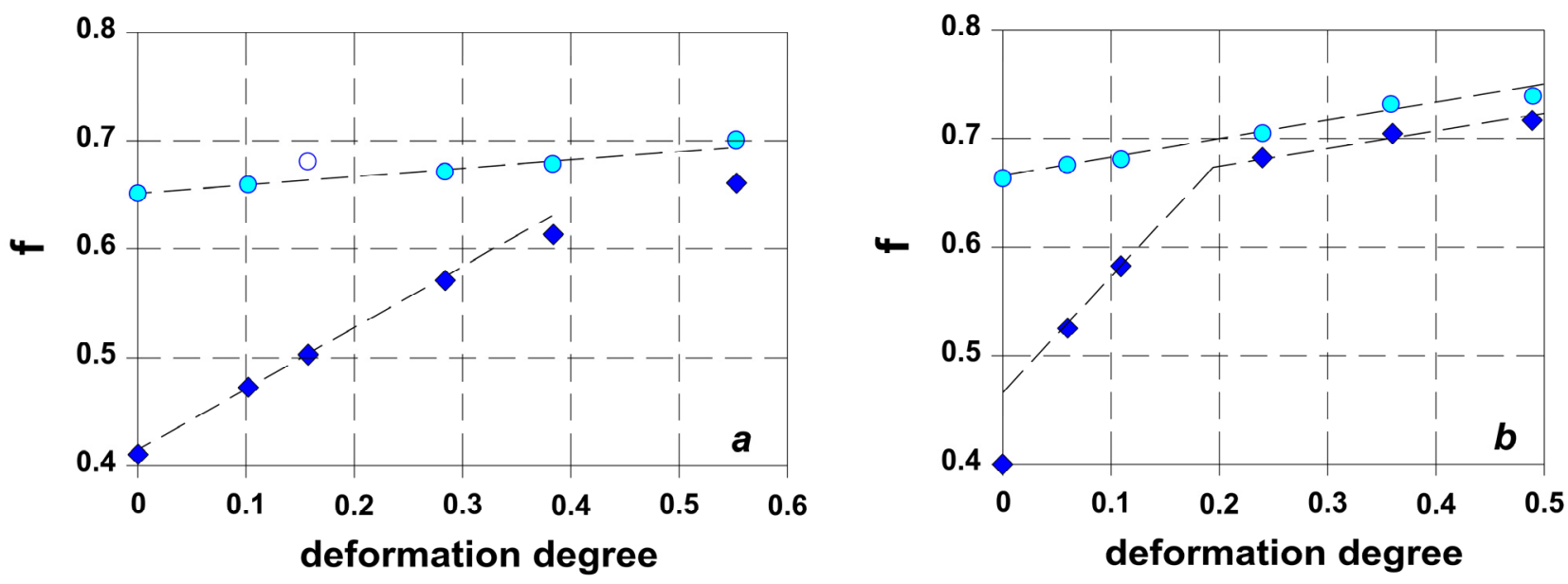

Fig. 3. Change in textural coefficient with degrees of deformation of plates during longitudinal (a) and cross rolling (b) [4]. Data from plate surfaces on the outside $(\bullet)$ and inside $(\circ)$ of original tube.

The second characteristic feature of Fig. 2 and, especially, Fig. 1 is the existence of an upper limit of linearity of graphs ( $A$ position; $\alpha=20 \ldots 25^{\circ}$ ) and a narrow area in $B$ position $\left(\alpha=55 \ldots 65^{\circ}\right)$ with exceeding its linear changes, which refers to neighborhood of the (1011) reflection line. According to Fig. 3a,b, the evolution of $B$ position and the formation of $A$ position as a maximum of the distribution are clearly observed in the second stage of texture changes with deformation. It is also meant that at the cross rolling of plates, for their near-surface areas - on the outside of the original tube, - the second stage begins approximately from $20 \%$ deformation (Fig. 3 b; black squares). At the same time, it is necessary to especially note the obvious connection between expression degree of $A$ and $B$ positions (Fig. 1,2).

Associated with the second stage for deformed medium of the material, the noted features which including the linearity of logarithmic graphs are similar to the results of such investigation of pure zirconium and hafnium [5]. 


\section{Analysis of tilt scanning data}

As noted above, in these studies another technique was used to analyze evolution of $c$-axes distributions in process of plate deformation.

Fig. 4 shows diagrams of tilt scanning (rocking curve measurements) of the original and deformed samples of both parties in (0004) reflection from the inner side of the original tube. Angular scanning was carried out in the plane of the transverse and longitudinal section of the samples (respectively, N-T and N-R scan) and represents $c$-axes angular distributions in these planes relative to ND. The graphs are located above each other by the single-unit interval of the ordinate grid. Scale parameters are identical for all fragments of the figure. The data, as noted above (Fig. 3), actually refer to the second stage of texture changes of the alloy with deformation.
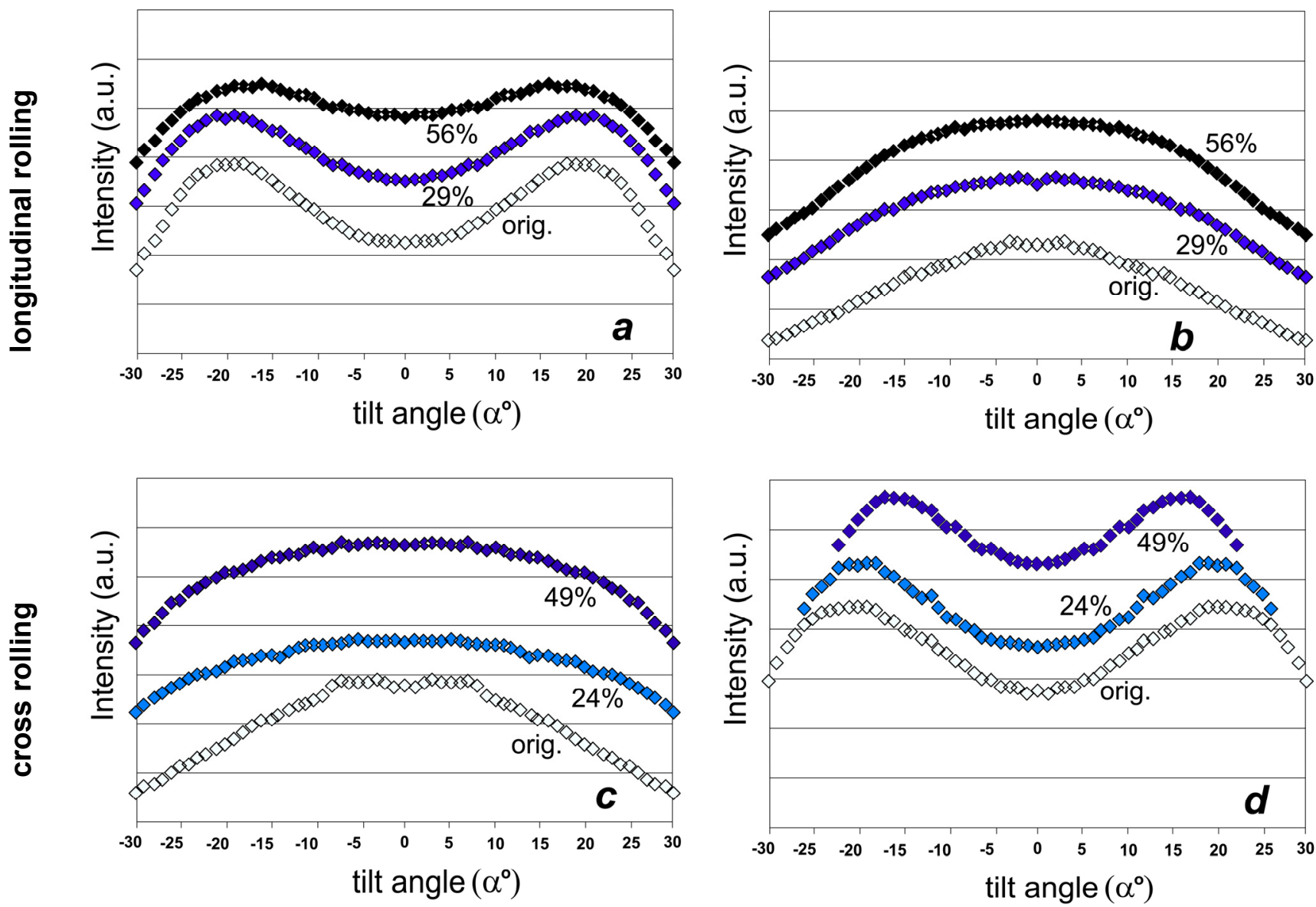

N-T scan

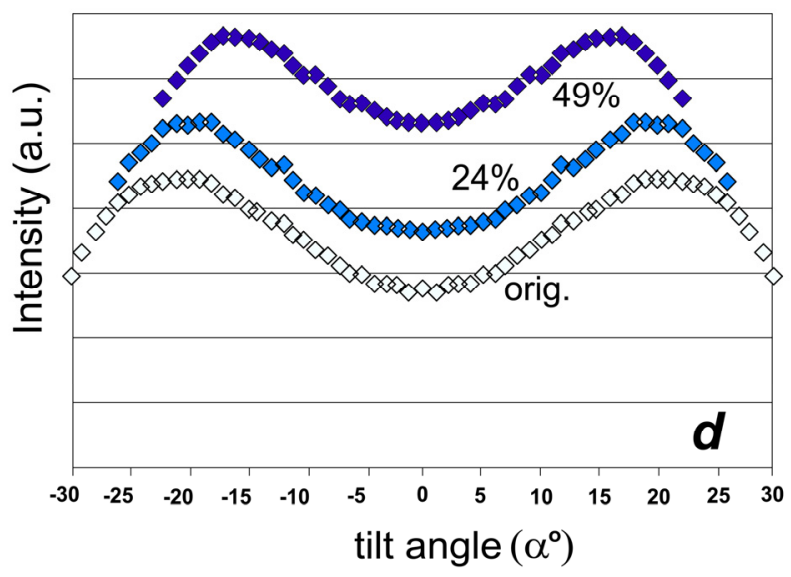

N-R scan

Fig. 4. Distributions of $c$-axes along cross ( $a, c)$ and longitudinal $(b, d)$ sections of longitudinally- $(a, b)$ and cross-rolled plates (c, d). Data from surfaces which corresponding to inner side of original tube; arbitrary units. Deformation degrees are indicated.

The double peak of the distributions (Fig. 4a,d) - a textural doublet with $\pm 20 \ldots 25^{\circ}$ maxima deviations from ND is unambiguously combined with the expression degree of the maximum of distributions in Fig. 1,2 ( $A$ position; $\alpha=20 \ldots 25^{\circ}$ ). Data on longitudinal rolling (Fig. 4a,b) represent evolution of the typical rolling texture of metals of the titanium subgroup with orientation of the doublet in the cross-sectional plane of the plates (N-T; perpendicular to RD). Data on cross rolling of the plates reflect an unusual situation with the direction of the doublet in the longitudinal section of the plates (perpendicular to TD; Fig. 4d), but a tendency to form such a doublet according to the typical scheme in the N-T plane also exists (Fig. 4c).

Fig. 5 presented in the same format, shows data of tilt scanning from the "outer" side of the plates. Fig. 5 actually reflects evolution of the textural features of Fig. 4, which should be considered characteristic of lower degrees of deformation, mainly for the initial stage of accelerated textural changes [4]. Here, this process shows some signs of instability, although this is practically not reflected in change regularity of the textural coefficient (Fig. 3). In the same time, these data confirm that the process of formation of the textural doublet occurs in the second stage. This follows, for example, from the scanning results for samples after their rolling with degrees above the order of $20 \%$. This is most expressed after cross rolling, especially in the N-R scan (Fig. 5d).

In general, the results indicate that the most characteristic textural changes occur along the cross-sectional plane of the original tube and at cross rolling of plates. 

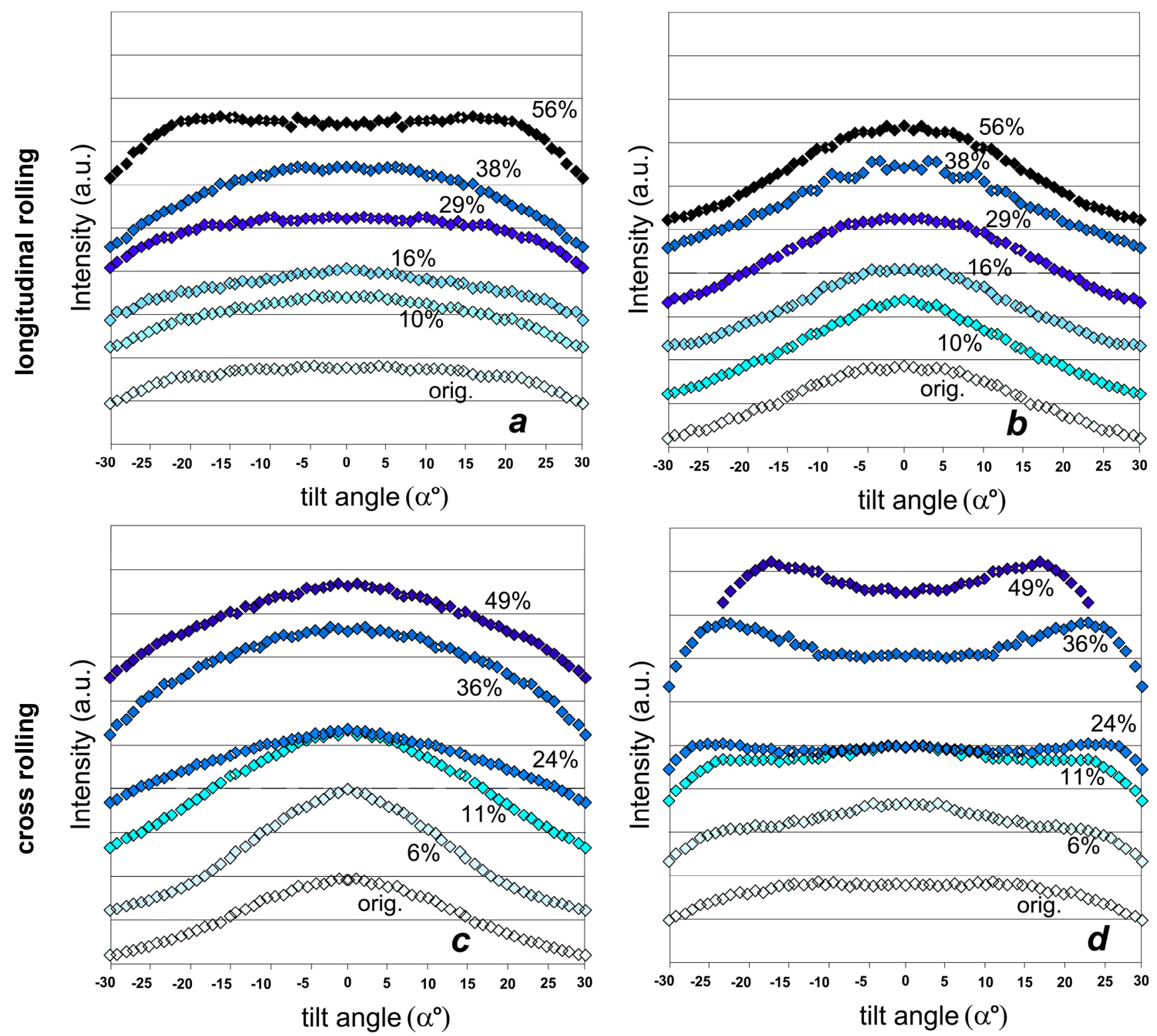

N-T scan

\section{N-R scan}

Fig. 5. Distributions of $c$-axes along cross (a, c) and longitudinal (b, d) sections of longitudinally- $(a, b)$ and cross-rolled plates (c, d).

Data from surfaces which corresponding to outer side of original tube; arbitrary units. Deformation degrees are indicated.

On twinning schemes of forming the texture at longitudinal and cross rolling of alloy

As was established [4], the reason of the accelerated rate of textural changes at the initial deformation stage of the alloy is activity of tensile twins of $\{10 \overline{1} 2\}[\overline{1011}]$ system. This system rotates $c$-axes of grains by $85^{\circ}$ [6]. The end of the initial stage was associated with significant reduction of the twinning substrate - a fraction of grains with a crystallographic orientation favorable for their subsequent twinning by this system.

From simple considerations, a decrease in activity of this twinning system at the end of the initial stage is further compensated by activity of other deformation systems. Thus, appearance of irregularity of the distributions (Fig. 1,2) in $B$ position $\left(\alpha=55 \ldots 65^{\circ}\right)$, mainly in the second stage, can be associated with activity of compression twins systems. These systems rotate $c$-axes through an angle of $60 \pm 5^{\circ}[6] .\{1011\}$ reflection in $B$ position can be caused either by rotation of the axes from the ND direction by $\{1011\}[10 \overline{12}]$ twin system or by rotation of the grains in this position around its own $c$-axes in result of action of prismatic slip systems.

In the non-ambiguity of the combination of $A\left(\alpha=20 \ldots 25^{\circ}\right)$ and $B$ positions (Fig. 1,2), what was noted above, a reason can be seen. So, if the real $A$ and $B$ positions were oriented in opposite directions from the ND normal (Fig. 6), then $\Delta \alpha$ interval between them would be $85^{\circ}$. This could be a sign of axes rotation from $B$ position $\left(B_{0}\right.$, Fig. 6$)$ to $A$ position directly by $\{10 \overline{1} 2\}[\overline{1011}]$ tensile twins system. In this case, $A$ position would be at an angle $28^{\circ}$.

Since $A$ position is associated with the textural doublet, such a scheme would represent the N-T plane for longitudinal rolling and the N-R plane for cross rolling of the plates as the plane of turns. $B_{0}$ (Fig. 6) displays $B$ position in 
these planes. However, as a result of additional measurements of the plates in the RD and TD directions, signs of $B_{0}$ position were not detected. In particular, the absence of such signs was noted from results of measurements of crossrolled plates in RD direction (rolling up to $49 \%$, Fig. 7; area of $\cos ^{2} \alpha=0.75 \ldots 0.85$ ). In part, this was due to the extremely low ability of $B_{0}$ position to appear in principle in RD and TD. This does not give grounds either to confirm or to disprove the ability of the sequence of $\{10 \overline{1} 1\}[\overline{1012}]$ and $\{10 \overline{1} 2\}[\overline{1011]}$ twinning systems to form $A$ position.

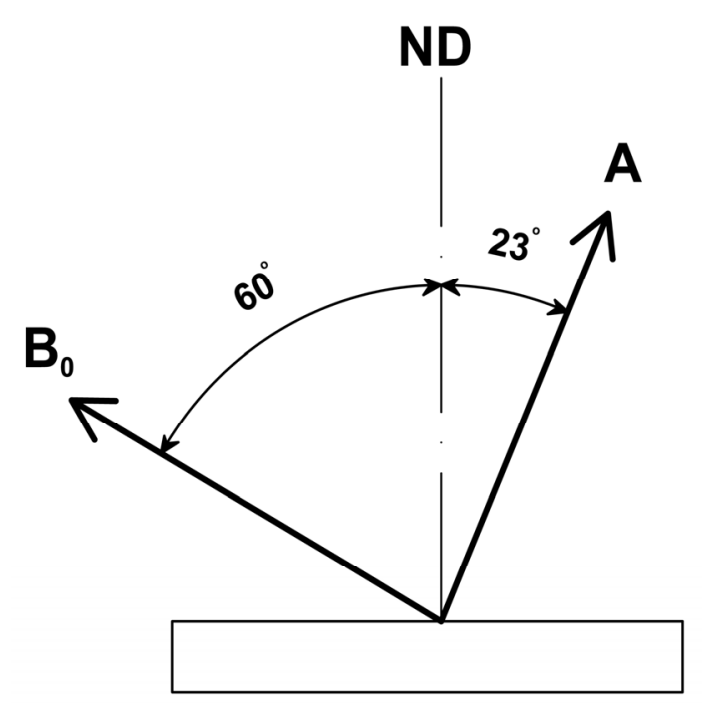

Fig. 6. Variant of location of $A$ and $B$ positions (Fig. 2.3). View in plane of longitudinal section of cross-rolled plates $(\mathrm{N}-\mathrm{R})$.

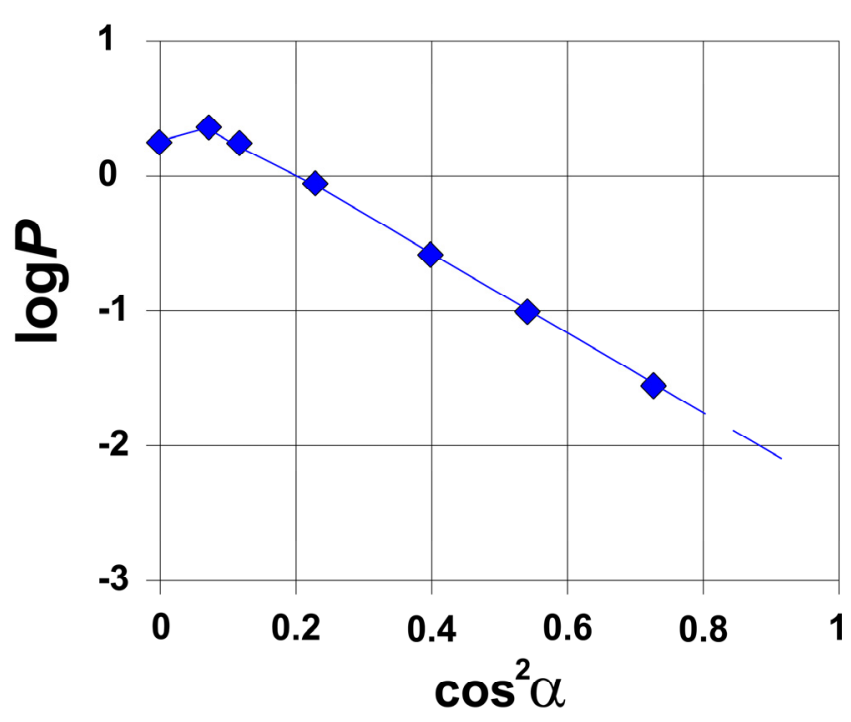

Fig. 7. Distribution of $c$-axes deviations from cross-rolling direction for $(h 0 \bar{h} l)$-reflecting positions. Common-logarithmic scale.

Thus, $B$ position remains only a sign of activity of the main systems of compression twins [6]. $\{11 \overline{2} 2\}[\overline{1} \overline{1} 23]$ system is the most active of these systems [7-9]. Its twins rotate $c$-axes of grains from the ND limits (measurement direction) to the angular position $B$. However, these grains take another foreshortening and are oriented in the ND direction by the normal of planes of the $\{h h \overline{2 h} l\}$ group corresponding to the "pyramid" of the second kind. Actually, that plane does not fall within the X-ray reflections area and does not appear in $B$ positions, although it gives orientation of $c$-axes in limits of this position $\left(\alpha=64.2^{\circ}\right)[6]$.

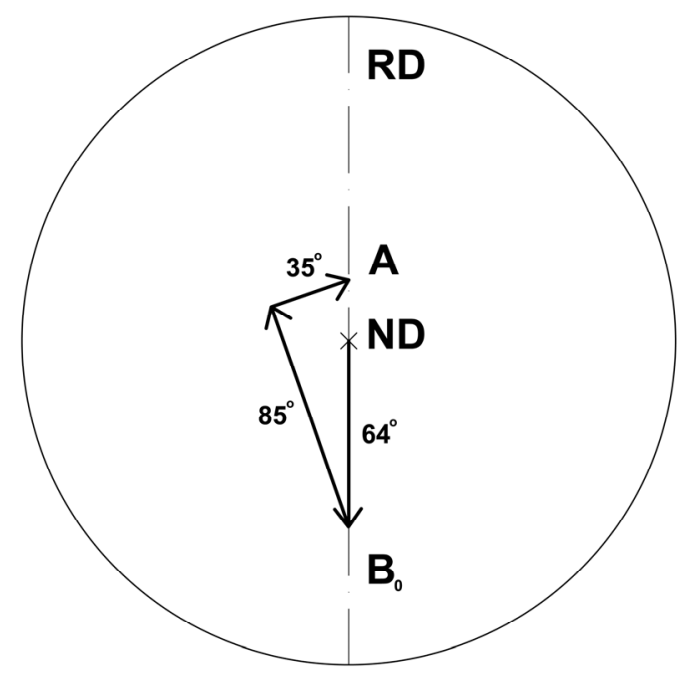

Fig. 8. Scheme of forming textural doublet by sequence of $c$-axis rotations. Cross-rolled samples.

As noted in [7-9], at deformation of zirconium and its alloys, such compression twins (of $\{11 \overline{2} 2\}[\overline{1} 1 \overline{2} 3]$ system) initiate $\{10 \overline{1} 2\}[\overline{1011]}$ system - the main system of tensile twins - as a second generation. However, their $\{1120\}$-plane of turns (of twinning shears) deviates by $30^{\circ}$ from the $\{1100\}$-plane of the primary turns. It was noted [8] that $\{11 \overline{2} 1\}[\overline{1} 126]$ system of tensile twins is accompanied with activity of $\{10 \overline{1} 2\}[\overline{1} 011]$ secondary twins. According to analysis of Fig. 4,5, and to formal concepts, it remains to conclude that these twins (first ones), participate in rotations the axes at an angle of $34.8^{\circ}$ [6], transfer them, from the plane of the previous turns, to $A$ position limits 
$\left(30^{\circ}-34.8^{\circ}\right.$; Fig. 8 ). The resulting rotation from $B$ position reaches an angle of $86^{\circ}$, and the final orientation ( $A$ position) is expected at an angle of $22^{\circ}$.

Such a scheme of formation of the textural doublet is most consistent with Fig. 4a,d and 5a,d. The probable traces of twinning by the previous scheme can be observed only at the beginning of the second textural stage in the cross rolling process (Fig. 5d; $24 \%$ deformation). In [7-9], no such signs were found.

On the example of pure zirconium, a noticeable slip contribution to texture changes with formation of the textural doublet is not expected [8].

This conclusion is done in relation to research data, mainly of cross-rolling samples. However, such conclusions formally apply to longitudinal rolling of this alloy.

\title{
SUMMARY
}

X-ray studies of effect of longitudinal and cross rolling on features of texture of plates made from blanks of the fuel assembly central tube of $\mathrm{Zr}-2.5 \% \mathrm{Nb}$ alloy used in RBMK reactor were carried out on the basis of the tilt scanning technique (rocking curve measurements) and an analysis of pole density distributions. As a result, the following has been established:

Most characteristic texture changes with longitudinal and cross rolling of plates up to $50 \%$ occur within the crosssectional plane of original tube and at cross rolling of plates.

In contrast to the initial stage of an increased rate of changes in Kearns textural coefficient, the subsequent stage of moderate changes is characterized by activity of compression twins and by process of formation of the textural doublet in distributions of $c$-axes of grains, that is more expressive along the cross-section plane of tube and at cross rolling of plates.

Probability of twinning schemes of formation of the textural doublet in process of alloy rolling was analyzed. The main schematic sequence of it is proposed:

- twinning by $\{11 \overline{2} 2\}[\overline{1} \overline{1} 23]$ system of compression twins rotating $c$-axes by $64^{\circ}$ from the normal to plate plane within the main plane of turns (cross section of the tube); direction;

- twinning by $\{1012\}[1011]$ system of tensile twins rotating these $c$-axes at an angle of $85^{\circ}$ in the nearly opposite

- participation of tensile twins of $\{11 \overline{2} 1\}[\overline{1} \overline{1} 26]$ system with rotations these $c$-axes to the main plane of turns (cross section of the tube).

\section{ORCID IDs}

Victor Grytsyna@https://orcid.org/0000-0003-4341-007X, Dmitry Malykhin@https://orcid.org/0000-0003-0259-0211, Tetiana Yurkova $@$ https://orcid.org/0000-0003-1264-640X, Kostiantyn Kovtun $@$ https://orcid.org/0000-0002-0524-5053, Gennadiy Kovtun 1 https://orcid.org/0000-0003-4242-7697

\section{REFERENCES}

[1] A. Nikulina, S. Shishov, B. Cox, F. Garzarolli and P. Rudling, Manufacturing of Zr-Nb Alloys, ZIRAT-11, Special Topic Report. ANT International, (Skultuna, Sweden, 2006), pp.45p.

[2] J.J. Kearns, Thermal expansion and preferred orientation in Zircaloy, WAPD-TM-472, (Westinghouse Electric Corporation, Pittsburg, USA, 1965).

[3] P.A. Tempest, J. Nucl. Mater. 92(2-3) (1980) pp.191-200, DOI: 10.1016/0022-3115(80)90102-6

[4] V. Grytsyna, D. Malykhin, T. Yurkova, K. Kovtun, T. Chernyayeva, G. Kovtun, V. Kornyeyeva, O. Slabospitskaya, I. Tantsura and V. Voyevodin, East-European Journal of Physics, 2, 39-45 (2019).

[5] G.P. Kovtun, K.V. Kovtun, D.G. Malykhin, T.S. Yurkova and T.Yu. Rudycheva, East-European Journal of Physics, 4(3), 36-42 (2017).

[6] E. Tenckhoff, J. of ASTM International, 2(4), 1-26 (2005), DOI: 10.1520/JAI12945.

[7] M. Zhang, B.F. Luan, Z.I. Song, R.I. Xin, K.I. Murty and Q. Liu, Scripta Materialia, 122, 77-81 (2016).

[8] Bai-feng Luan, Qing Ye, Jian-wei Chen, Hong-bing Yu, Dong-li Zhou and Yun-chang Xin, Trans. Nonferr. Met. Soc. China 23(10), 2890-2895 (2013), in: https://www.sciencedirect.com/science/article/abs/pii/S100363261362811 3

[9] R.J. McCabe, G. Proust, E.K. Cerreta and A. Misra, Int. J. of Plast. 25(3), 454-472 (2009), DOI: 10.1016/j.ijplas.2008.03.010

\author{
ПРО СТРУКТУРНІ АСПЕКТИ ТЕКСТУРНИХ ЗМІН ПРИ ПРОКАТЦІ СПЛАВУ Zr-2.5\% \\ Грицина В.М. ${ }^{1}$, Малихін Д.Г. ${ }^{1}$, Юркова Т.С. ${ }^{1}$, Ковтун К.В. ${ }^{3}$, \\ Чернясва Т.П. ${ }^{1}$, Ковтун Г.П. ${ }^{1,2}$, Танцюра І.Г. ${ }^{1}$, Восводін В.М. ${ }^{1}$ \\ ${ }^{l}$ ННЦ «Харківський фізико-технічний інститут» НАНУ \\ Украӥна, 61108, г. Харків, ул. Академічна 1 \\ ${ }^{2}$ Харківский національний університет ім. В.Н. Каразіна \\ Україна, 61022, м. Харків, майдан Свободи, 4 \\ ${ }^{3}$ ДП «НТЦ «Бериліӥ» НАНУ \\ Україна, 61108, м. Харків, вул. Академічна 1
}

Методом рентгеноструктурного аналізу досліджено особливості змін характеристик кристалографічної текстури при холодній деформації пластин зі сплаву $\mathrm{Zr}-2,5 \% \mathrm{Nb}$ поздовжньої і поперечної прокатки. Матеріалом для виготовлення вихідних пластин були поздовжні фрагменти і кільця труби $\varnothing 15,0 \times 1,5$ мм²$^{2}$, відпалені при $580{ }^{\circ} \mathrm{C}$. Прокатка пластин здійснювалася 
при кімнатній температурі в інтервалі від 6 до 56\% у ступінчастому режимі з кроком 5...7\% і швидкістю $5 \ldots 10$ сек ${ }^{-1}$ На основі методу зворотних полюсних фігур з дифрактометрічною зйомкою за оптичною схемою Брега-Брентано визначалась густина відбиття вздовж нормалі до площини пластин сплаву (щільність полюсів). За цими даними проведено аналіз розподілу орієнтацій кристалографічних осей «с» ГЩУ-решітки матеріалу. Виявлено локальні особливості розподілів, які було віднесено до ознак прояви двійникувания в змінах текстури пластин. При подальшому аналізі було враховано ефект неоднорідності деформації, пов'язаний з передісторією пластин. Встановлено, що друга стадія (помірних) змін текстурного параметру Кернса зі ступенем деформації пластин відрізняється від початкової стадії прискорених змін активізацією двійників стиснення. Методом зйомок кривих хитання з регістрацією інтенсивностей відбиття (0004) навколо центральної позиції досліджено зміни розподілів орієнтації осей «с» в поздовжньому і поперечному перетині пластин сплаву обох партій. Відзначено, що основні текстурні зміни в процесі деформації пластин здійснюються в площині поперечного перетину вихідної труби і найбільш виражені на пластинах поперечної прокатки. Дублет в розподілі осей «с», що характерний для текстури прокатки ГЩУ-металів титанової підгрупи, відзначено на другій стадії текстурних змін у матеріалі, зокрема - 3 його спрямованістю уздовж площини поперечного перетину вихідної труби. Виявлено зв'язок особливостей розподілів щільності полюсів зі ступенем вираженості текстурного дублету на кривих хитання. Згідно з отриманими результатами та аналізом інших публікацій підтверджено двійникову природу текстурного дублету і запропоновано схематичну послідовність його формування за участю двійників стиснення системи $\{11 \overline{2} 2\}\langle\overline{1} \overline{1} 23\rangle$ і двійників розтягування систем $\{10 \overline{1} 2\}\langle\overline{1} 011\rangle$ та $\{11 \overline{2} 1\}\langle\overline{1} \overline{1} 26\rangle$.

КЛЮЧОВІ СЛОВА: сплави цирконію, прокатка, рентгенографія, текстура, двійникування.

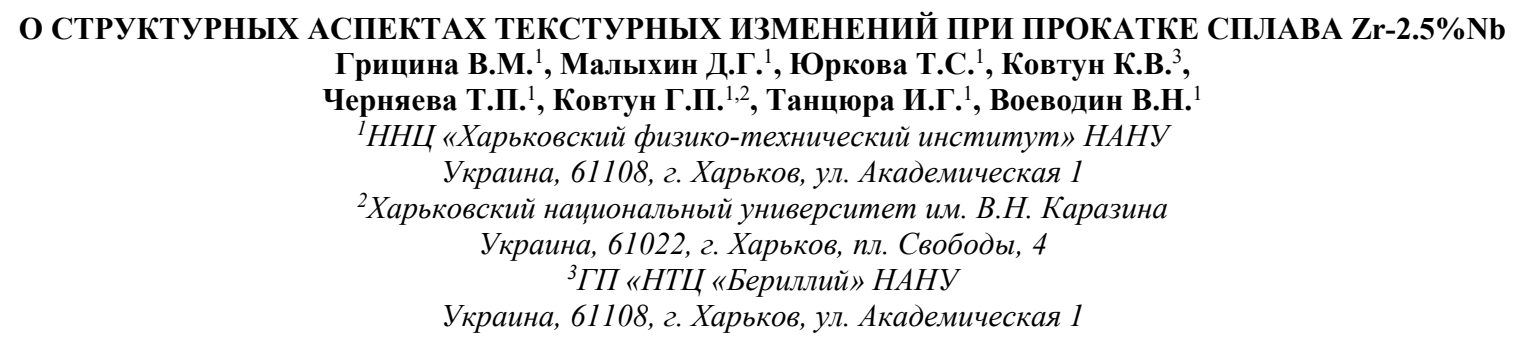

Методом рентгеноструктурного анализа исследованы особенности изменений характеристик кристаллографической текстуры при холодной деформации пластин из сплава $\mathrm{Zr}-2,5 \% \mathrm{Nb}$ продольной и поперечной прокаткой. Материалом для изготовления исходных пластин были продольные фрагменты и кольца трубы $\varnothing 15,0 \times 1,5$ мм $^{2}$, отожжённые при $580{ }^{\circ} \mathrm{C}$. Прокатка пластин осуществлялась при комнатной температуре в интервале от 6 до $56 \%$ в ступенчатом режиме с шагом $5 \ldots 7 \%$ и со скоростью $5 \ldots 10$ сек $^{-1}$. На основе метода обратных полюсных фигур с дифрактометрической съёмкой по оптической схеме Брэгга-Брентано определялась плотность отражений вдоль нормали к плоскости пластин сплава (плотность полюсов). По этим данным проведен анализ распределения ориентаций кристаллографических осей «с» ГПУ-решётки материала. Выявлены локальные особенности распределений, которые были отнесены к признакам проявления двойникования в изменениях текстуры пластин. При последующем анализе учтён эффект неоднородности деформации, связанный с предысторией пластин. Установлено, что вторая стадия (умеренных) изменений текстурного параметра Кернса со степенью деформации пластин отличается от начальной стадии ускоренных изменений активизацией двойников сжатия. Методом съёмок кривых качания с регистрацией интенсивности отражения (0004) исследованы изменения распределений ориентации осей «с» в продольном и поперечном сечении пластин сплава для обеих партий. Отмечено, что основные текстурные изменения в процессе деформации пластин осуществляются в плоскости поперечного сечения исходной трубы и наиболее выражены на пластинах поперечной прокатки. Дублет в распределении осей «с», характерный для текстуры прокатки ГПУ-металлов титановой подгруппы, отмечен на второй стадии текстурных изменений в материале. Его направленность в основном связывается с плоскостью поперечного сечения исходной трубы. Выявлена связь особенностей распределений плотности полюсов со степенью выраженности текстурного дублета на кривых качания. Согласно полученным результатам и анализу других публикаций подтверждена двойниковая природа текстурного дублета и предложена схематическая последовательность его формирования с участием двойников сжатия системы $\{11 \overline{2} 2\}\langle\overline{1} \overline{1} 23\rangle$ и двойников растяжения систем $\{10 \overline{1} 2\}\langle\overline{1} 011\rangle$ та $\{11 \overline{2} 1\}\langle\overline{1} \overline{1} 26\rangle$.

КЛЮЧЕВЫЕ СЛОВА: сплавы циркония, прокатка, рентгенография, текстура, двойникование. 